\title{
Corporate Social and Environmental Reporting Institutionalized
}

\author{
René P. Orij \\ Leiden University, Leiden, the Netherlands
}

\begin{abstract}
External Corporate Social and Environmental Reporting (CSER) finds its raison d'être in corporations' search for both a license to operate and accountability towards society. This suggests a relationship between corporations and society. In this study, that relationship is analyzed, specifically the relationship between levels of CSER and economic institutions. A strong link with institutions is an outcome of institutionalization. The economic institutions applied are economic freedom and legal origin as a proxy for national corporate governance systems. The results of this descriptive study show associations between CSER levels and economic freedom. CSER is also related to national corporate governance systems through legal origin. CSER appears to be institutionalized, or in any case, corporations seem to be aware of the economic institutionalization of CSER.
\end{abstract}

Keywords: social and environmental reporting, economic institutions, stakeholders, legitimacy

\section{Introduction}

The major idea behind this study is the existence of the systems orientation of businesses. In other words, businesses are parts of the system society, which is expressed through corporate reporting. Corporate Social and Environmental Reporting (CSER) relates to the systems orientation. With CSER, corporations show their social and environmental performance to society or specific groups within society. This study contains an empirical search for societal determinants of CSER. In this study, societal determinants are societal institutions, societal moulds. Three types of institutions exist: economic, social, and political. In this paper, only economic institutions are studied.

Institutions exist both formally and informally. Laws are examples of formal institutions. Institutions are humanly determined constraints on human interaction, as described by North (1990). In order to be able to analyze voluntary behavior, informal institutions are chosen. Associations between CSER and the economic institutional environment are analyzed with the use of a system-theoretical framework. The framework consists of two theories: stakeholder theory and legitimacy theory. Hypotheses with regard to the associations studied are drawn from these theories. Both theories are applied at a national level. National institutions are suggested to be related to corporate-level reporting. The hypotheses are assessed with the use of an economic-institutional regression model.

Economic institutions are seen as the most relevant in the field of financial accounting by Ball, Kothari, and Robin (2000) and in the field of assurance of CSER by Simnett, Vanstraelen, and Chua (2009). The two studies limit the economic institutions by legal origin only.

The research problem of this study is whether an association exists between CSER levels and economic institutions. This emerges from the institutional moulds, which are determinants of actions by system participants - the corporations.

René P. Orij, assistant professor, Department of Business Studies, Leiden University. Email: r.p.orij@law.leidenuniv.nl. 
After the introduction, this article continues with a description of prior literature. Then, a discussion on methodology is given. The theoretical framework and hypotheses development are given thereafter, followed by a section on the results of the statistical and hypotheses testing. Then, the article is finalized with conclusions.

\section{Prior Literature}

This study assumes the existence of a CSER sub-paradigm within financial accounting research. The theoretical framework that has links with financial accounting theory, as suggested by Deegan and Unerman (2006), is applied. CSER research also has ties with strategic management research, as is shown by Ullmann (1985). A somewhat large body of literature is available, and part of this body is discussed in this section.

The review of literature is done in three parts. First, studies are discussed that have a focus on the use of theory. Next, this paper discusses studies that search for institutional determinants of CSER. At the end of this section, other studies are discussed that search for determinants in other contexts.

Ullmann (1985) published an important article on CSER in 1985, in which he stated that no clear theory is available to describe links between levels of CSER and strategic corporate goals. He suggested that stakeholder theory may be applicable to explain "data in search of a theory" (Ullmann, 1985). He also tried to describe a relationship between corporate financial performance and CSER. Many other authors have tried to do the same, as is described by Orlitzky and Benjamin (2001).

Gray, Owen, and Maunders (1988) provided a basis for the application of legitimacy theory in CSER research. Adams, Hill, and Roberts (1998) applied legitimacy theory to describe CSER. They searched for corporate and national characteristics that have an effect on CSER. They explained the differences between CSER levels by the differences in how corporations deal with legitimacy issues at a national level. They studied institutions, but did not clearly mention this. Among the national differences, they mentioned government ideology of economic freedom as an economic institution, culture as a social institution, and environmental and labor laws as political institutions. Size of corporations is also said to determine CSER levels because of a corporate search for legitimacy. Adams et al. (1998) suggested an association between economic institutions and CSER that is caused by government ideology on free markets. They hypothesized that ideology causes corporations to behave in line with norms of external social and environmental stakeholders, as the opposite behavior may lead to legal restrictions on economic freedom; informal institutions may lead to formal institutions. They explained this behavior as a result of a search for legitimacy, which is similar to an implicit license to operate. Newson and Deegan (2002) stated that culture has an effect on CSER, because culture influences the way corporations deal with legitimacy.

Van der Laan Smith, Adikhari, and Tondkar (2005) assessed a sample of US and Scandinavian corporations with a combined framework of culture as a social institution and legal origin as a proxy for national corporate governance systems, an economic institution. Code law is supposed to be stakeholder-oriented and common law is supposed to be shareholder-orientated. They found support for their hypothesis that CSER is associated with both legal systems and culture.

Simnett et al. (2009) applied legal origin as a proxy for the difference between national stakeholder and shareholder orientations at an institutional level. They found support for their statement that a stakeholder orientation is associated with the level of CSER assurance.

Orij (2010) built further on Van der Laan Smith et al. (2005) and related CSER to stakeholder theory and culture. 
In CSER research, little attention is given to economic institutions as a determinant of disclosure compared to mainstream financial accounting research. In financial accounting research, Ball et al. (2000) related economic institutions to properties of accounting earnings. Other financial accounting studies by Hope (2003a; 2003b) and Hope, Kang, Thomas, and Yoo (2008) studied determinants that relate to enforcement of accounting regulation, auditor choice, legal systems, and culture. With regard to the discussion on legal origin, they referred to the research paradigm of law and economics and the specific study by La Porta, Lopez-de-Silanes, Shleifer, and Vishny (1999). The latter also provides detailed data on code law sub-groups. They stated that clear differences exist among French, German, and Nordic code laws, which may affect national corporate governance systems.

\section{Methodology}

CSER research can be classified as interpretative or sometimes critical research. A positive, theory-verification research methodology is chosen in order to be able to draw generic conclusions. In this study, descriptives of CSER are looked for through the search for associations between CSER and economic institutions.

The regular focus of mainstream research on decision usefulness for investment purposes of all external corporate reporting is not applied. There are two reasons for not using that approach. The first is that this study focuses on outside determinants that have an internal effect. An outside-in approach is applied, as is described by Burritt and Schaltegger (2010). The second reason is theoretical. The system-oriented approach that is applied in most CSER research suggests that everything in society is interrelated. The corporation-shareholder relationship is not the only relevant relationship for corporate reporting, especially not for CSER. The raison d'être for CSER is societal, not solely economic, which is one of the fundamental premises of this study.

Hypotheses are developed out of a theoretical framework and prior literature. The hypotheses are tested with the use of statistical material from a large sample of CSER data. The data provided by Sustainalytics consist of 600 corporations from 22 countries. The selection of corporation originates from the MSCI World Index (MSCI Barra, 2010). The statistical analysis consists of multivariate regression models, supported by bivariate correlations. Independent variables are country data on institutions. The dependent variable is the CSER score provided by Sustainalytics. Further details on the CSER score are provided below.

The main methodological limitation of this study is its static character; only one year, 2012, is studied. Institutions are supposed to be "fluid", a general characteristic of institutions nowadays, as Bauman (2007) stated.

\section{Theoretical Framework and Hypotheses Development}

The theoretical framework consists of stakeholder theory, legitimacy theory, and institutions from institutional theory. Institutions will be discussed firstly. Thereafter, legitimacy theory and stakeholder theory are discussed. After the discussion on the theoretical framework, hypotheses are developed.

Institutions have been defined by North (1990) in his institutional theory. He recognized three types of institutions: economic, social, and political. Institutions are social phenomena. They are patterns in society - constraints created by people, which can be ideological or ethical. Institutions are not set forever. They may change, particularly through globalization. Bauman (2007) described this and Stiglitz (2007) related it to multinational corporations. In this study, it is assumed that corporations may be "asked" to adapt to 
societal institutions. Corporations are assumed to show their adaptation to the institutions by their CSER. The motives for adaptation may be found in other theories. The other theories are system-oriented theories that explain corporate behavior, stakeholder theory, and legitimacy theory. These system-oriented theories are seen as part of a financial accounting research paradigm by Deegan and Unerman (2006). These theories describe the relations between the society as a system and the corporation.

Stakeholder theory has been developed by Freeman (1984). According to this theory, the corporation directs its activities towards the interests of several stakeholders, in such way as it is described by Mitchell, Agle, and Wood (1997).

Related to stakeholder theory are the concepts of communitarianism and contractarianism. These concepts define stakeholder orientation at a national level. Communitarianism stands for a society which is oriented towards responsibility and sharing equally (Bradley, Schipani, Sundaram, \& Walsh, 1999). Contractarianism stands for a society in which individual freedom and interests stand first. In recent research, communitarianism has also been linked to a stakeholder orientation or a social orientation of the society (Simnett et al., 2009). With that assumed theoretical relationship, the connection between institutions and social orientation at a national level can be established.

Legitimacy theory originates from the social contract of Rousseau (2003, original publication in 1762) and other enlightenment philosophers. Legitimacy is an informal contract with society, and legitimacy of corporations is sometimes called license-to-operate. It may also be seen as the social acceptance of the corporation. A corporation may deal with legitimacy at three different levels: creating legitimacy, preserving legitimacy, or regaining legitimacy (Suchman, 1995). Legitimacy theory suggests that social pressure relating to legitimacy differs for every particular corporation. Corporations in certain risky industries experience larger pressures than others, and large corporations experience more pressure than small ones. Legitimacy theory is generally applied at an organizational level, as Suchman (1995) described. Newson and Deegan (2002) applied the theory at a national level. They suggested that differences exist internationally concerning the search for organizational legitimacy. They related their outcomes to a combination of cultural and economic institutions.

The theoretical framework and the hypotheses development are visualized in Figure 1.

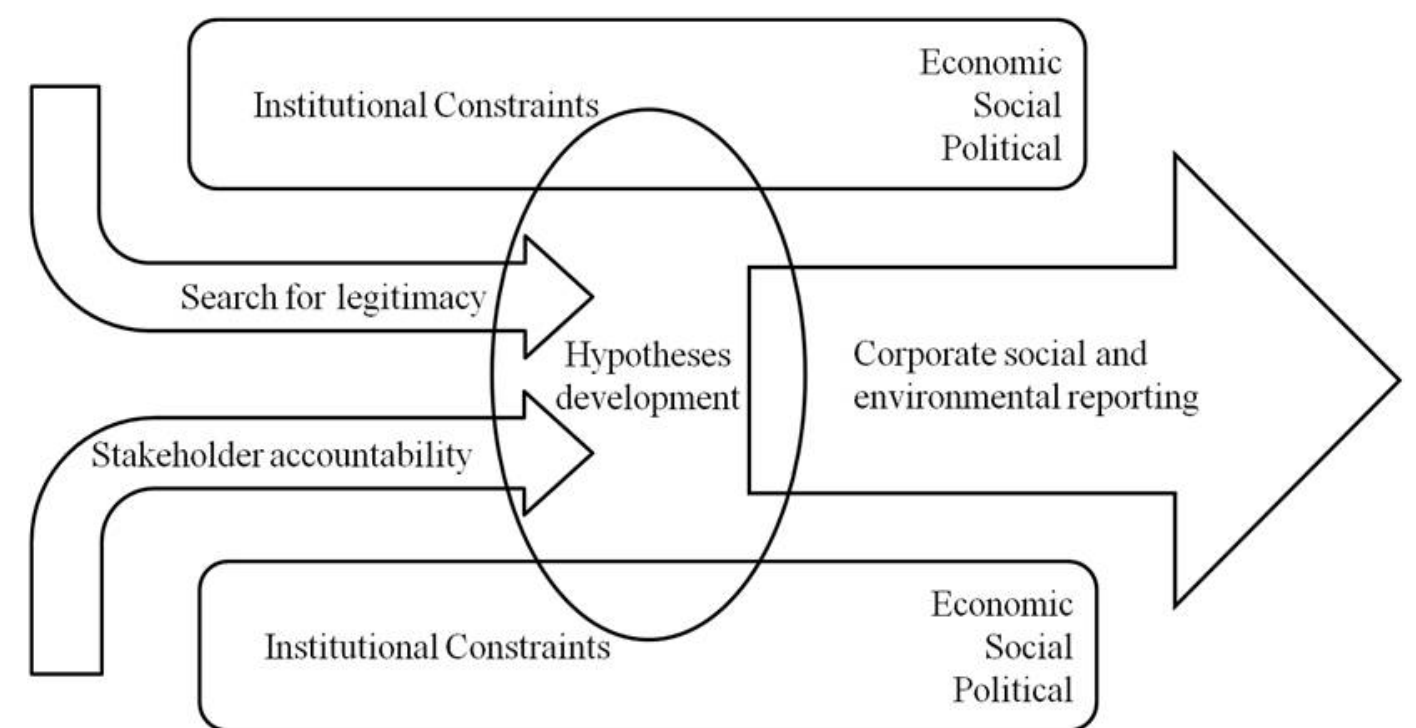

Figure 1. Visualization of relationships between theoretical framework and hypotheses development. 
The size of this study only allows searching for relationships between the level of CSER and one type of institution. Only economic institutions are studied. The economic institutions studied are national corporate governance systems and government free market ideology, that is to say, economic freedom, which may be seen as the level to which governments favor capitalism. The national corporate governance systems relate to legal origin of the country involved. The relationship between corporate governance and legal systems can only be established through stakeholder theory and communitarianism. The latter suggests that a stakeholder orientation within nations may be caused by a social orientation that relates to the legal origin. A stakeholder orientation leads to a corporate focus on stakeholder accountability, which further leads to a higher level of CSER. Code law leads to a stakeholder orientation, whereas common law systems lead to a shareholder orientation. Common law is seen as the opposite with regard to social orientation. This reasoning leads to the following hypothesis:

H1: Legal origin and its related national corporate governance system are associated with the level of CSER through a negative association with common law and a positive association with code law.

Prior studies, such as Simnett et al. (2009), confirmed the theoretical associations, as suggested by stakeholder theory and communitarianism. Legal origin in $\mathrm{H} 1$ can only be related to stakeholder issues instead of legitimacy issues. There is no proof of the relevance of legitimacy issues with regard to legal origin.

H1 suggests legal origin to be an explanatory variable, which differs from Orij (2010). In that study, legal origin was a control variable, as culture was the main issue to be studied.

A further hypothesis is based upon free market ideology. The existence of a relationship between levels of CSER and free market ideology is suggested by Adams et al. (1998). They suggested a positive association. Corporations want to keep freedom intact, and for this reason, they try to please the lawmakers with the use of CSER. Corporations are supposed to deal with lawmakers in a similar manner as is explained by the political cost hypothesis from positive accounting theory (PAT). Milne (2002) linked CSER to PAT.

However, another reasoning may be possible. Orij (2012) suggested that the relationship between levels of CSER and free market ideology can be explained by a national stakeholder orientation, similar to legal origin. The reasoning behind this suggestion is as follows: The higher the level of economic freedom, the fewer the corporations willing to deal with stakeholders other than shareholders. Free markets do not coincide with a stakeholder orientation. Therefore, levels of CSER are likely to be negatively associated with economic freedom.

The discussion on this hypothesis leads to two sub-hypotheses:

H2a: Economic freedom is positively associated with levels of CSER, through national levels of legitimacy-seeking corporate behavior.

$\mathrm{H} 2 \mathrm{~b}$ : Economic freedom is negatively associated with levels of CSER, through stakeholder-oriented corporate behavior.

The two sub-hypotheses suggest opposite directions of the relationships. The possible outcomes of H2a and $\mathrm{H} 2 \mathrm{~b}$, which conflict, are shown in Table 1.

In brief, Table 1 describes which sub-hypothesis, $\mathrm{H} 2 \mathrm{a}$ or $\mathrm{H} 2 \mathrm{~b}$, can be confirmed, if a particular association is found. Concluded from the analysis in Table 1 may be that depending on the direction of the association, H2a or $\mathrm{H} 2 \mathrm{~b}$ can be confirmed, not both at the same time. 
Table 1

Possible Outcomes of Opposing H2a and H2b

\begin{tabular}{|l|l|l|}
\hline Possible strength of theoretical relationships & $\begin{array}{l}\text { Possible empirical } \\
\text { relationship found }\end{array}$ & Possible confirmation of hypotheses \\
\hline $\begin{array}{l}\text { Positive legitimacy effect is suggested to be } \\
\text { stronger than negative stakeholder effect on } \\
\text { CSER. } \\
\text { Overall effect is suggested to be positive. }\end{array}$ & $\begin{array}{l}\text { The empirical test shows that the positive effects are stronger } \\
\text { than the negative effects. The positive legitimacy effect can be } \\
\text { confirmed. The negative stakeholder effect cannot be } \\
\text { confirmed, as it seems to disappear within the larger } \\
\text { legitimacy effect. } \\
\text { H2a can be confirmed. H2b cannot be confirmed. }\end{array}$ \\
\hline $\begin{array}{l}\text { Positive legitimacy effect is suggested to be } \\
\text { weaker than negative stakeholder effect on } \\
\text { CSER. } \\
\text { Overall effect is suggested to be negative. }\end{array}$ & $\begin{array}{l}\text { The negative stakeholder effect is found to overrule the positive } \\
\text { legitimacy effect, if it exists, as the empirical test shows that the } \\
\text { negative effects are stronger than the positive effects. } \\
\text { Both H2a and H2b cannot be confirmed. }\end{array}$ \\
\hline $\begin{array}{l}\text { Positive legitimacy effect is stronger than } \\
\text { negative stakeholder effect. } \\
\text { Overall effect is suggested to be positive. }\end{array}$ & $\begin{array}{l}\text { The positive legitimacy effect is found to overrule the negative } \\
\text { stakeholder effect, if it exists, as the empirical test shows that } \\
\text { the negative effects are stronger than the positive effects. } \\
\text { Both H2a and H2b cannot be confirmed. }\end{array}$ \\
\hline $\begin{array}{l}\text { Positive legitimacy effect is weaker than } \\
\text { negative stakeholder effect. } \\
\text { Overall effect is suggested to be negative. }\end{array}$ & $\begin{array}{l}\text { The negative stakeholder effect is suggested to overrule the } \\
\text { positive legitimacy effect. The empirical test shows that the } \\
\text { negative effects are stronger than the positive effects. } \\
\text { The positive legitimacy effect can be confirmed, but the } \\
\text { negative stakeholder effect cannot be confirmed; H2a cannot } \\
\text { be confirmed, while H2b can be confirmed. }\end{array}$ \\
\hline
\end{tabular}

\section{Sample, Data, and Operationalization}

In this paper, a sample from 2012 is studied. The sample contains 3,553 companies from 56 countries. The selection of the sample and the contents of the database are based upon all available information provided by Sustainalytics, an international corporate social responsibility (CSR) research company. The dataset is compiled by a content analysis of the companies' publicly available reports and interviews done by Sustainalytics. The scoring system is based upon a combined assessment of the quantity and quality of CSR activities by companies. A description of the assessment methods by Sustainalytics is available to the author. Sustainalytics aims to collect CSR data from all companies included in the "World Index". The collection of the Sustainalytics data has been a combined effort by the SiRi group of research institutes, originally also including Kinder Lydenberg Domini (KLD). KLD data are used in the majority of CSR and CSER studies (Orlitzky \& Benjamin, 2001) and are useful data, as Sharfman (1996) demonstrated. The availability of CSR data is the bottleneck in CSR research, which makes these data the starting point for the sample selection (Sharfman, 1996). A similar approach to application of the data is done in Orij (2010), but with older data (2006) and other combinations of variables.

Industry or sector data are also provided by Sustainalytics. The variable on sector data is a dummy variable that scores the membership of an industry group or sector. GSCI sector data consist of 10 sectors, which lead to nine dummy variables (sector (STR)).

Institutional data come from several sources and these are values per nation. The first economic institution is economic freedom (ECF), as suggested by Adams et al. (1998). They did not assess this variable, but hypothesized a relationship with CSER. A relevant source is Simnett et al. (2009). They applied data by Kaufmann, Kraay, and Mastruzzi (2009). Kaufmann et al. (2009) applied data on economic freedom by the Heritage Foundation (2012), a US think tank on conservatism and economic freedom. 
Data on corporate governance system, particularly its legal origin basis, are taken from La Porta et al. (1999). Corporate governance as an economic institution is represented by a dummy variable for legal origin, as Van der Laan Smith et al. (2005) and Simnett et al. (2009) suggested. Hope (2003a) applied detailed sub-groups of legal systems: French (FRE), German (GER), and Nordic (NOR) code laws. La Porta et al. (1999) provided the fifth ${ }^{1}$ type of legal origin: socialist. Table 2 shows these data per country.

Table 2

\section{Country Data}

\begin{tabular}{|c|c|c|c|}
\hline Country & Number of companies & Legal origin & Economic freedom \\
\hline Australia & 186 & Common & 95.5 \\
\hline Austria & 32 & German & 73.6 \\
\hline Bahamas & 1 & Common & 69.2 \\
\hline Belgium & 19 & French & 91.6 \\
\hline Bermuda & 12 & Common & 45.4 \\
\hline Brazil & 78 & French & 53.0 \\
\hline Canada & 249 & Common & 91.7 \\
\hline Cayman Islands & 1 & Common & 58.9 \\
\hline Channel Islands & 4 & Common & 25.2 \\
\hline Chile & 15 & French & 70.5 \\
\hline China & 117 & Socialist & 48.0 \\
\hline Colombia & 8 & French & 90.2 \\
\hline Cyprus & 2 & Common & 80.7 \\
\hline Czech Republic & 3 & Socialist & 65.8 \\
\hline Denmark & 21 & Nordic & 98.4 \\
\hline Egypt & 9 & French & 63.3 \\
\hline Finland & 22 & Nordic & 94.8 \\
\hline France & 125 & French & 84.0 \\
\hline Germany & 162 & German & 92.1 \\
\hline Greece & 10 & French & 77.1 \\
\hline Hong Kong & 101 & Common & 98.9 \\
\hline Hungary & 4 & Socialist & 79.1 \\
\hline India & 91 & Common & 37.3 \\
\hline Indonesia & 27 & French & 20.2 \\
\hline Ireland & 21 & Common & 83.4 \\
\hline Israel & 19 & Common & 66.1 \\
\hline Italy & 35 & French & 76.9 \\
\hline Japan & 347 & German & 81.3 \\
\hline Luxembourg & 8 & French & 74.8 \\
\hline Macau & 2 & French & 60.0 \\
\hline Malaysia & 39 & Common & 79.9 \\
\hline Mauritius & 1 & Common & 78.2 \\
\hline Mexico & 23 & French & 81.4 \\
\hline Morocco & 3 & French & 76.4 \\
\hline The Netherlands & 74 & French & 57.2 \\
\hline New Zealand & 7 & Common & 99.9 \\
\hline Norway & 17 & Nordic & 92.6 \\
\hline
\end{tabular}

\footnotetext{
${ }^{1}$ The five types are FRE, GER, NOR, SOC, and common law.
} 
(Table 2 continued)

\begin{tabular}{|c|c|c|c|}
\hline Country & Number of companies & Legal origin & Economic freedom \\
\hline Papua New Guinea & 1 & Common & 58.3 \\
\hline Peru & 2 & French & 72.3 \\
\hline The Philippines & 18 & French & 72.3 \\
\hline Poland & 22 & Socialist & 64.0 \\
\hline Portugal & 10 & French & 82.8 \\
\hline Russia & 29 & Socialist & 69.2 \\
\hline Singapore & 37 & Common & 97.1 \\
\hline South Africa & 46 & Common & 74.7 \\
\hline South Korea & 75 & German & 93.6 \\
\hline Spain & 51 & French & 80.3 \\
\hline Sweden & 36 & Nordic & 93.2 \\
\hline Switzerland & 55 & German & 75.8 \\
\hline Taiwan & 106 & German & 94.3 \\
\hline Thailand & 23 & Common & 73.2 \\
\hline Turkey & 23 & French & 68.2 \\
\hline Ukraine & 1 & Socialist & 47.6 \\
\hline United Arab Emirates & 2 & Common & 74.0 \\
\hline UK & 138 & Common & 94.1 \\
\hline US & 983 & Common & 90.5 \\
\hline Total & 3,553 & & \\
\hline
\end{tabular}

Note. Sources: Legal origin: La Porta et al. (1999); Economic freedom: Heritage Foundation (2012).

Table 3 shows the descriptive statistics of the variables.

Table 3

Descriptive Statistics

\begin{tabular}{|c|c|c|c|c|c|}
\hline Variable & $N$ & Minimum & Maximum & Mean & Standard deviation \\
\hline CSER & 3,553 & 0.00 & 275.00 & 30.1435 & 53.86289 \\
\hline$E C F$ & 3,553 & 252.00 & 999.00 & 834.6696 & 147.16631 \\
\hline
\end{tabular}

Notes. CSER is corporate social and environmental reporting. ECF is economic freedom. Sources: CSER: Sustainalytics; ECF: Heritage Foundation (2012).

\section{Results}

In this section, results of various statistical tests are shown: correlations, $T$-tests, and regression models. The results from the statistical tests are used further in the hypotheses testing.

In Table 4, bivariate Pearson correlations among variables CSER, ECF, and legal origin are shown.

In Table 4, it is shown that CSER correlates significantly with all variables, except for COM. None of the bivariate correlations is alarmingly high, as very high correlations may disturb other associations. The significance of the detailed code law dummies with COM is obvious, as these score 0 , while COM scores 1 .

In Table 5, results of bivariate $T$-tests are shown, which provide evidence on the differences in mean CSER levels between the legal origins.

The results from Table 5 show that the CSER level differs between many of the legal origins. As suggested before, it is likely that corporations from code law countries score higher than those from common law countries. But the outcomes of the $T$-tests do not support the suggested difference. The only type of legal origin that shows significant differences in CSER levels is socialist legal origin. These are lower than all other levels. 
Table 4

Bivariate Pearson Correlations (Two-Sided)

\begin{tabular}{llllllc}
\hline Variable & COM & FRE & GER & NOR & SOC & $E C F$ \\
\hline COM & 1 & $-0.471^{* *}$ & $-0.588^{* *}$ & $-0.188^{* *}$ & $-0.251^{* *}$ & $0.337^{* *}$ \\
FRE & & $-0.224^{* *}$ & $-0.072^{* *}$ & $-0.096^{* *}$ & $-0.350^{* *}$ \\
GER & & 1 & $-0.090^{* *}$ & $-0.119^{* *}$ & $0.084^{* *}$ \\
NOR & & & 1 & $-0.038^{*}$ & $0.118^{* *}$ \\
SOC & & & & 1 & $-0.446^{* *}$ \\
ECF & & & & & 1 \\
\hline
\end{tabular}

Notes. CSER is corporate social and environmental reporting. ECF is economic freedom. COM is common law. FRE is French code law. GER is German code law. NOR is Nordic code law. SOC is socialist legal origin. ${ }^{*}: p<0.05 .{ }^{* *}: p<0.01$. Sources: CSER: Sustainalytics; COM, FRE, GER, NOR, and SOC: La Porta et al. (1999); ECF: Heritage Foundation (2012).

Table 5

T-tests' CSER and Legal Origin

\begin{tabular}{lrllccl}
\hline Test & d.f. & $\begin{array}{l}\text { CSER mean: } \\
\text { 1st variable }\end{array}$ & $\begin{array}{l}\text { CSER mean: } \\
\text { 2nd variable }\end{array}$ & Diff. & T-value & $\begin{array}{l}\text { Significance } \\
(2 \text {-tailed) }\end{array}$ \\
\hline COM-COD & 3,048 & 30.92 & 30.11 & 0.81 & 0.427 & 0.669 \\
COM-SOC & 2,133 & 30.92 & 21.59 & $9.33^{*}$ & 2.198 & 0.028 \\
COD-SOC\# & 1,588 & 30.11 & 21.59 & $8.52^{*}$ & 1.984 & 0.047 \\
COM-all other & 3,427 & 30.92 & 29.19 & 1.73 & 0.956 & 0.339 \\
FRE-all other & 3,551 & 27.53 & 30.61 & -3.09 & -1.229 & 0.219 \\
GER-all other & 3,551 & 32.46 & 29.50 & 2.96 & 1.355 & 0.175 \\
NOR-all other & 104 & 25.80 & 30.27 & -4.47 & -0.826 & 0.411 \\
SOC-all other & 3,551 & 21.59 & 30.58 & $-8.99^{*}$ & -2.782 & 0.033 \\
COM-FRE & 2,503 & 30.92 & 27.53 & 3.39 & 1.314 & 0.189 \\
COM-GER & 1,340 & 30.92 & 32.46 & -1.54 & 0.635 & 0.526 \\
COM-NOR & 109 & 30.92 & 25.80 & 5.12 & 0.936 & 0.351 \\
COM-SOC\# & 2,133 & 30.92 & 21.59 & $9.33^{*}$ & 2.198 & 0.028 \\
FRE-GER & 1,317 & 27.53 & 32.46 & -4.93 & -1.615 & 0.107 \\
FRE-NOR & 130 & 27.53 & 25.80 & 1.73 & 0.302 & 0.763 \\
FRE-SOC & 341 & 27.53 & 21.59 & 5.94 & 1.589 & 0.113 \\
GER-NOR & 130 & 32.46 & 25.80 & 6.66 & 1.163 & 0.247 \\
GER-SOC & 947 & 32.46 & 21.59 & $10.87^{*}$ & 2.324 & 0.020 \\
NOR-SOC & 164 & 25.80 & 21.59 & 4.21 & 0.683 & 0.496
\end{tabular}

Notes. This table uses two-sided $T$-tests. CSER is corporate social and environmental reporting. COM is common law. COD is code law. FRE is French code law. GER is German code law. NOR is Nordic code law. SOC is socialist legal origin. Sample size is 3,553. d.f. is degree of freedom. Sources: CSER: Sustainalytics; COM, FRE, GER, NOR, and SOC: La Porta et al. (1999). \#: shown twice to be consistent.

In the next part of this section, the regression models are suggested and assessed. The basic model, Model 1, contains the dependent variable CSER and the independent variables COM and ECF score by the Heritage Foundation. The model also contains the control variables for the sector. The model does not contain any company-specific economic variables, as no theoretical foundation for that inclusion is available. The following model is suggested to assess all hypotheses:

$$
C S E R=\beta_{0}+\beta_{1} E C F+\beta_{2} C O M+S T R+e
$$

The nine STR dummies are not shown separately in the table. 
The second model contains the detailed legal origin sub-groups, instead of the straightforward distinction between code law and common law countries:

$$
C S E R=\beta_{0}+\beta_{1} E C F+\beta_{2} F R E+\beta_{3} G E R+\beta_{4} N O R+\beta_{5} S O C+\beta_{6} S T R+e
$$

The third model will be tested without the SOC group. The classic distinction between common and code law legal origins is hypothesized. The model is similar to Model 1.

The exclusion of one part of the dataset is based upon this classic distinction. Legal origin has never been hypothesized as having a relationship with corporate governance systems:

$$
C S E R=\beta_{0}+\beta_{1} E C F+\beta_{2} C O M+\beta_{6} S T R+e \quad(\text { Without SOC Legal Origin) (Model 3) }
$$

The results of the regression models are shown in Table 6.

Table 6

\begin{tabular}{|c|c|c|c|}
\hline Variable & $\begin{array}{l}\text { Model } 1 \\
\text { CSER described by economic } \\
\text { freedom, legal origin, and } \\
\text { sector }\end{array}$ & $\begin{array}{l}\text { Model } 2 \\
\text { CSER described by economic } \\
\text { freedom, legal origin in detail, } \\
\text { and sector }\end{array}$ & $\begin{array}{l}\text { Model } 3 \\
\text { CSER described by economic } \\
\text { freedom, legal origin, and sector, } \\
\text { without socialist legal origin }\end{array}$ \\
\hline Constant & $18.180^{* *}$ & $25.34^{* * *}$ & $1.098^{* * *}$ \\
\hline COM & 0.882 & & $-0.150^{* * *}$ \\
\hline$E C F$ & 0.007 & -3.50 & $0.00013^{* *}$ \\
\hline$F R E$ & & 1.47 & \\
\hline$G E R$ & & -3.83 & \\
\hline$N O R$ & & -8.10 & \\
\hline$S O C$ & & -0.00 & \\
\hline$S T R$ & $\begin{array}{l}\text { Dummy, consisting of nine } \\
\text { items, some }^{* * *}\end{array}$ & $\begin{array}{l}\text { Dummy, consisting of nine } \\
\text { items, some }\end{array}$ & $\begin{array}{l}\text { Dummy, consisting of nine } \\
\text { items, some }^{* * *}\end{array}$ \\
\hline$F$ & $11.344^{* * *}$ & $13.987^{* * *}$ & $67.432^{* * *}$ \\
\hline Adj. $R$-squared & 0.039 & 0.039 & 0.217 \\
\hline
\end{tabular}

Regression Models That Describe CSER Levels

Notes. First line is coefficient. Second line is $T$-value. CSER is corporate social and environmental reporting. ECF is economic freedom. COM is common law. FRE is French code law. GER is German code law. NOR is Nordic code law. STR is sector. SOC is socialist legal origin. $F$ is $F$-statistic of the analysis of variance (ANOVA). ${ }^{* * *}: p<0.001,{ }^{* *}: p<0.01,{ }^{*}: p<0.5$. Sources: CSER: Sustainalytics; COM, FRE, GER, NOR, and SOC: La Porta et al. (1999); ECF: Heritage Foundation (2012); STR: Sustainalytics.

Before a full analysis of the regression models can be provided, an analysis of the expected signs is given (see Table 7). The variable legal origin, as the distinction between corporations from common law and code law countries, is supposed to score negatively. The dummy variable scores 1 for common law and 0 for code law. The expected negative association is explained by the shareholder orientation within common law countries.

The direction of the ECF variable may vary with the explanatory theory (see Table 1).

Table 7

Signs of Variables

\begin{tabular}{lll}
\hline Variable & Expected sign & $\begin{array}{l}\text { Empirically found sign } \\
\text { (Model 3) }\end{array}$ \\
\hline$E C F$ & - or $+\#$ & + \\
$C O M$ & - & - \\
\hline
\end{tabular}

Notes. ECF is economic freedom. COM is common law. \#: direction dependent on the explanatory power of two theories (see Table 1). 
Now we follow the analysis of the results given in Tables 6 and 7. All three models in Table 6 are significant on the whole, as can be seen by the significance of the $F$-statistic. For the first two, the significance is most probably caused by the industry variables. Models 1 and 2 show no significance for any of the main variables. The total dataset seems to be out of balance. The companies that relate to the non-hypothesized socialist legal origin are taken out for Model 3, which works out well. The main variables COM, legal origin, and ECF contribute significantly to Model 3.

For Model 3, the contribution of COM is consistent with the expectations, according to Table 7. The contribution of ECF is positive, also consistent with expectations, as is suggested by stakeholder theory according to Table 7 , as both signs may occur, depending on the theoretical backing.

With older data (2006), Orij (2012) found other conclusions, though one important addition is made here: the separation between socialist legal origin and the others.

On the basis of the prior results, H1 can be confirmed: The legal origin and the related corporate governance system are determinants of corporate levels of CSER; legal origin up to the level of the distinction between code law and common law and with the specific additional conclusion about socialist legal origin. Not all legal systems and related corporate governance systems are determinants of CSER, in particular, socialist legal origin and the related corporate governance systems cannot be confirmed as a determinant of CSER. The bivariate analyses show that particularly the socialist legal origin matters particularly in a negative way. The multivariate analysis also confirms the significance of the common law-code law distinction on legal origin, as was hypothesized.

The analysis of $\mathrm{H} 2 \mathrm{a}$ and $\mathrm{H} 2 \mathrm{~b}$ is based upon all possible outcomes of the confrontation of hypotheses and findings in Table 1. The positive impact by legitimacy-related motives may "overrule" possible smaller, negative effects suggested by stakeholder theory. Only the negative impact can be confirmed, which leads to a confirmation of $\mathrm{H} 2 \mathrm{~b}$. H2a cannot be confirmed. Overall, economic freedom is confirmed as a determinant of CSER, particularly through legitimacy-related motives. The sector effects also contribute to that conclusion.

\section{Conclusions and Discussion}

In this study, a relationship has been established between CSER and the economic-institutional environment of corporations. These economic institutions are economic freedom and the national corporate governance systems. The latter are represented by the legal origins of the nations. This was shown to be relevant, as a corporate governance-systematic determinant of CSER, but not generically. Common law and code law systems are relevant determinants, but socialist legal origin is not.

Further, the economic institution of government ideology that promotes economic freedom has a positive impact on CSER levels. This ideology is the level to which government favors economic freedom. More capitalism relates to more legitimacy-oriented social and environmental reporting. This effect is disturbed by companies from countries with a socialist legal origin, which shows low economic freedom and low levels of CSER. The latter can only clearly be shown in the correlation table, as the regressions do not show significant associations.

In general, a relationship among economic institutions can be confirmed, though less clear than initially expected. CSER is somewhat institutionalized with regard to economic institutions. 


\section{References}

Adams, C. A., Hill, W. Y., \& Roberts, C. B. (1998). Corporate social reporting practices in Western Europe: Legitimating corporate behaviour? The British Accounting Review, 30(1), 1-21.

Ball, R., Kothari, S. P., \& Robin, A. (2000). The effect of international institutional factors on properties of accounting earnings. Journal of Accounting and Economics, 29(1), 1-51.

Bauman, Z. (2007). Liquid times: Living in an age of uncertainty. Cambridge: Polity Press.

Bradley, M., Schipani, C. A., Sundaram, A. K., \& Walsh, J. P. (1999). The purposes and accountability of the corporation in contemporary society: Corporate governance at a crossroads. Law and Contemporary Problems, 62(3), 9-86.

Burritt, R. L., \& Schaltegger, S. (2010). Sustainability accounting and reporting: Fad or trend? Accounting, Auditing, and Accountability Journal, 23(7), 829-846.

Deegan, C., \& Unerman, J. (2006). Financial accounting theory. Maidenhead: McGraw-Hill Education.

Freeman, R. E. (1984). Strategic management: A stakeholder approach. Boston: Pitman.

Gray, R., Owen, D., \& Maunders, K. (1988). Corporate social reporting: Merging trends in accountability and the social contract. Accounting, Auditing, and Accountability Journal, 1(1), 6-20.

Heritage Foundation. (2012). Index of economic freedom. Retrieved from http://www.heritage.org/Index/pdf/2012/book/Index_2012.pdf

Hope, O. K. (2003a). Disclosure practices, enforcement of accounting standards, and analysts' forecast accuracy: An international study. Journal of Accounting Research, 41(2), 235-272.

Hope, O. K. (2003b). Firm-level disclosures and the relative roles of culture and legal origin. Journal of International Financial Management and Accounting, 14(3), 218-248.

Hope, O. K., Kang, T., Thomas, W., \& Yoo, Y. K. (2008). Culture and auditor choice: A test of the secrecy hypothesis. Journal of Accounting and Public Policy, 27(5), 357-373.

Kaufmann, D., Kraay, A., \& Mastruzzi, M. (2009). Governance matters VIII: Aggregate and individual governance indicators, 1996-2008. Washington: The World Bank.

La Porta, R., Lopez-de-Silanes, F., Shleifer, A., \& Vishny, R. (1999). The quality of government. Journal of Law, Economics, and Organization, 15(1), 222-279.

Milne, M. J. (2002). Positive accounting theory, political costs, and social disclosure analyses: A critical look. Critical Perspectives on Accounting, 13(3), 369-395.

Mitchell, R. K., Agle, B. R., \& Wood, D. J. (1997). Toward a theory of stakeholder identification and salience: Defining the principle of who and what really counts. Academy of Management Review, 22(4), 853-886.

MSCI Barra. (2010). Global investable market indices methodology.

Newson, M., \& Deegan, C. (2002). Global expectations and their association with corporate social disclosure practices in Australia, Singapore, and South Korea. The International Journal of Accounting, 37(2), 183-213.

North, D. C. (1990). Institutions, institutional change, and economic development. Cambridge: Cambridge University Press.

Orij, R. P. (2010). Corporate social disclosures in the context of national cultures and stakeholder theory. Accounting, Auditing, and Accountability Journal, 23(7), 868-889.

Orij, R. P. (2012). Societal determinants of corporate social disclosures. Leiden: Leiden University Press.

Orlitzky, M., \& Benjamin, J. D. (2001). Corporate social performance and firm risk: A meta-analytic review. Business and Society, 40(4), 369-396.

Rousseau, J. J. (2003). On the social contract. Mineola: Dover Publications.

Sharfman, M. (1996). The construct validity of the Kinder, Lydenburg, \& Domini social performance ratings data. Journal of Business Ethics, 15(3), 287-296.

Simnett, R., Vanstraelen, A., \& Chua, W. F. (2009). Assurance on sustainability reports: An international comparison. The Accounting Review, 84(3), 937-967.

Stiglitz, J. E. (2007). Making globalization work. New York, NY: Norton.

Suchman, M. C. (1995). Managing legitimacy: Strategic and institutional approaches. Academy of Management Journal, 20(3), 571-610.

Ullmann, A. A. (1985). Data in search of a theory: A critical examination of the relationships among social performance, social disclosure, and economic performance of U.S. firms. Academy of Management Review, 10(3), 540-557.

Van der Laan Smith, J., Adikhari, A., \& Tondkar, R. H. (2005). Exploring differences in social disclosures internationally: A stakeholder perspective. Journal of Accounting and Public Policy, 24(2), 123-151. 